УДК 659.4:640.43

DOI: https://doi.org/10.26642/jen-2019-4(90)-33-37

А.Ю. Могилова, д.е.н., проф.

М.А. Вознюк, магістр

Дніпровський начіональний університет імені Олеся Гончара

\title{
Формування комплексу заходів Public relations на підприємствах громадського харчування
}

\begin{abstract}
Досліджено теоретичні питання формування комплексу заходів Public relations на підприємствах громадського харчування. Проаналізовано стан розвитку конкурентної боротьби на ринку громадського харчування. Встановлено, щяо формування позитивного іміджу закладу громадського харчування - найважливіший чинник у боротьбі за залучення потенційних відвідувачів, він відображає якість та ефективність маркетингової діяльності в иілому. Окреслено необхідність проведення заходів Public relations для підприємств громадського харчування в сучасних умовах ведення бізнесу. Вивчені підходи до трактування поняття "Риblic relations» та встановлена ключова мета PR-акцій. Розглянуто класифікацію за основними напрямами та особливості використання комплексу заходів Public relations в ресторанному бізнесі. Визначено ключові напрями діяльності по зв'язках з громадськістю у закладах громадського харчування. Розглянуто зовнішні та внутрішні PR-інструменти, які використовують заклади громадського харчування, та основні завдання маркетингових комунікацій. Наведено етапи основних програм більшості технологій «Public relations». Охарактеризовано фактори, щзо впливають на розробку тактики PR-звернень. Визначено сегменти ринку громадського харчування та надано характеристику елементів просування. Виокремлено проблеми ефективності застосування окремих елементів просування. Досліджено роль PR у досягненні ефективної роботи організацій. Розглянуто формування $і$ дослідження громадської думки та способи впливу на громадську думку.
\end{abstract}

Ключові слова: маркетинг; комунікація; зв'язки з громадськістю; громадське харчування, управління.

Постановка проблеми. Сучасні умови функціонування закладів сфери громадського харчування обумовлюють ключові стратегічні орієнтири їх діяльності та розвитку на базі формування й активного застосування інформаційних технологій. Посилення конкуренції на ринку громадського харчування зумовлює необхідність застосування в цій складній конкурентній боротьбі закладами нових переваг, наявність яких напряму залежить від ступеня застосування PR-заходів, включення сформованого компанією іміджу до вирішення поставлених завдань, інтеграції в систему керування процесами, котрі проходять як всередині закладу, так і при його взаємодії із зовнішнім оточенням. Український ресторанний бізнес не відразу зрозумів ефективність засобів public relations, однак останніми роками заклади громадського харчування усвідомили важливість та актуальність зв'язків з громадськістю. Формування позитивного іміджу закладу громадського харчування - найважливіший фактор у боротьбі за залучення потенційних відвідувачів, за перехід реальних клієнтів до постійних. Задля успішного функціонування в закладі громадського харчування усю діяльність, думки усіх працівників має пронизувати турбота про імідж закладу. Саме тому тема є актуальною.

Аналіз останніх досліджень і публікацій. Питання, пов'язані 3 PR-діяльністю підприємства, розглядаються в працях провідних зарубіжних та українських вчених: I.Ансоффа [1], I.Білик [2], В.Буторіна [3], Ф.Вірсема [8], О.Вовчанська [4], Е.Гладских [5], Ж.-Ж. Ламбена [6], Г.Мінцберга [10], М.Портера [7], К.Прахалада [11], М.Трейсі [12-13], Г.Хамеля [9], Ф.І. Хміля та ін.

Виділення не вирішених раніше частин загальної проблеми. Аналіз досліджень вчених дав змогу побачити існування зовсім різних підходів до класифікації PR-заходів, інколи навіть суперечливих, що говорить про необхідність у більш детальному вивченні та класифікації засобів Public Relations в закладах громадського харчування.

Мета статті. Головною метою цієї роботи є дослідження теоретичних засад формування комплексу заходів Public relations на підприємствах громадського харчування та виявлення комплексу факторів, що впливають на розробку ефективної тактики PR-звернень.

Викладення основного матеріалу. За даними досліджень компанії Nielsen, станом на вересень 2018 р. в 6 обласних містах України (Києві, Львові, Одесі, Харкові, Запоріжжі та Дніпрі) функціонувало 10994 підприємства сфери громадського харчування. Найбільшу частку з них складали заклади типу кафе і ресторанів - 46 \% (5 009 од.). Компаній у категорії Fast Food - 40 \% (4 427 од.), найменшу частку склали бари, паби та нічні клуби - 14 \% (1 558 од.) [5].

(C) А.Ю. Могилова, М.А. Вознюк, 2019 
Public relations - це створення громадської думки, формування репутації і керування репутацією закладу громадського харчування. В цілому ресторанний бізнес являється однією з найскладніших сфер господарської діяльності. Грамотно організована PR-кампанія - ключовий момент у просуванні закладу громадського харчування. Ключова мета PR-акції - це формування постійної клієнтури закладу громадського харчування, яка не просто зайшла б до нього одного разу заради інтересу, а стала б постійно відвідувати даний заклад [2].

Методів просування послуг та продуктів на ринку існує дуже багато, проте не всі підходять саме для закладів громадського харчування. Що стосується певних напрямів просування, які застосовуються в закладах громадського харчування, то можна виокремити такі: пряма реклама, персональні продажі, стимулювання збуту та Public relations (далі PR). Якщо керівник закладу буде просувати свій ресторан, застосовуючи усі 4 напрями, то це значно збільшить ймовірність максимального успіху.

Здебільшого, масштабні PR-акції проводяться великими мережами ресторанів, що входять у ресторанний ланцюг та фінансуються іноземними інвесторами. Зважаючи на пережитки минулого, доводиться конструювати новий образ, що відповідає вимогам ринку. Брак фінансових ресурсів визначено гальмує здійснення PR-діяльності.

Public relations $\epsilon$ формою комерційної політики, що спрямована на завоювання сприятливої думки окремих соціальних, професійних груп або конкретних особистостей, створення іміджу закладу громадського харчування. PR поряд з рекламою і стимулюванням збуту є найважливішим інструментом ресторанного маркетингу.

Маркетингова діяльність закладів громадського харчування має забезпечити:

1. Надійну, достовірну і своєчасну інформацію про ринок, структуру і динаміку конкретного попиту, смаки і переваги покупців, тобто інформацію про зовнішні умови функціонування закладу готельноресторанного господарства;

2. Надання таких послуг та виробництво товарів, що найбільш повно задовольняють вимоги ринку, більш ніж послуги конкурентів.

3. Необхідний вплив на споживача, на попит, на ринок, що забезпечує максимально можливий контроль сфери реалізації.

Залежно від того, які цілі PR і на кого він спрямований, виокремлюють декілька його різновидів (табл. 1).

Класифікачія заходів Public relations [3, с. 16]

Таблиия 1

\begin{tabular}{|c|c|c|}
\hline $\begin{array}{c}\text { Напрям } \\
\text { класифікації }\end{array}$ & Основні види & Характеристика \\
\hline \multirow[t]{3}{*}{$\begin{array}{l}\text { За сферою } \\
\text { використання }\end{array}$} & Комерційний & $\begin{array}{l}\text { Споживчий - при виведенні на ринок нових видів товару, коли } \\
\text { треба запевнити насторожених споживачів у високій репутації } \\
\text { фірми-виробника; фінансовий - об’єктом PR-компаній стають } \\
\text { також потенційні інвестори, владні структури, працівники самої } \\
\text { фірми; кризовий - коли треба ліквідувати негативні наслідки кризи }\end{array}$ \\
\hline & Політичний & $\begin{array}{l}\text { Почав розвиватися в епоху представницької демократії, коли } \\
\text { політичним лідерам стало необхідно переконувати найширші кола } \\
\text { виборців голосувати за них }\end{array}$ \\
\hline & Міжнародний & $\begin{array}{l}\text { Спрямований на досягнення взаєморозуміння між громадянами } \\
\text { різних країн, незважаючи на культурні відмінності }\end{array}$ \\
\hline \multirow{2}{*}{$\begin{array}{l}3 \text { огляду на } \\
\text { виконавця }\end{array}$} & Власний підрозділ & - \\
\hline & Аутсорсинг & Залучення PR-агенції \\
\hline \multirow{3}{*}{$\begin{array}{c}\text { За } \\
\text { поведінковою } \\
\text { реакцією }\end{array}$} & Соціальний PR & Використовується для формування позитивних моделей поведінки \\
\hline & Вірусний PR & $\begin{array}{l}\text { Поширюється сам по собі через спілкування між людьми, головне } \\
\text { придумати цікаву тему, яку обговорюватимуть (влаштувати флеш-моб) }\end{array}$ \\
\hline & Конфліктний PR & $\begin{array}{l}\text { Методи конфліктного піару застосовують у сферах зіткнення } \\
\text { інтересів (конкуренції, протистояння бізнесу і держави) }\end{array}$ \\
\hline \multirow{4}{*}{$\begin{array}{l}3 \text { огляду на } \\
\text { етику }\end{array}$} & Білий PR & $\begin{array}{l}\text { «Чесний», непроплачений PR. Прийоми «білого» піару чітко } \\
\text { поділяються за результатами: для споживача, для компанії і для } \\
\text { персоналу компанії }\end{array}$ \\
\hline & Зелений PR & $\begin{array}{l}\text { Заснований на корпоративній відповідальності в галузі захисту } \\
\text { навколишнього середовища }\end{array}$ \\
\hline & Жовтий PR & $\begin{array}{l}\text { Використання, } 3 \text { метою залучення уваги, образливих для читачів } \\
\text { елементів }\end{array}$ \\
\hline & Чорний PR & $\begin{array}{l}\text { Використання «чорних технологій» (обману) для обмовляння, } \\
\text { знищення конкурентів, розповсюдження від їх імені образливих } \\
\text { або економічно небезпечних заяв та ін. }\end{array}$ \\
\hline
\end{tabular}


Ресторанний бізнес в Україні залишається одним з найбільш цікавих і прибуткових для українських підприємців. Щорічно в Україні відкриваються елітні ресторани, фаст-фуди, готельно-ресторанні комплекси тощо.

Одним із недоліків роботи закладів громадського харчування є недосконала система маркетингу. Узагальнюючою характеристикою ефективності діяльності ресторанного бізнесу по підтримці діяльності та ефективності використання потенціалу підприємства може слугувати імідж компанії, який він має серед споживачів на сучасному етапі. Адже імідж закладів громадського харчування відображає якість та ефективність маркетингової діяльності в цілому.

Виокремлюють 5 ключових напрямів діяльності по зв’язках з громадськістю у закладах громадського харчування:

- взаємовідносини зі ЗМІ (паблісіті) - формування новини про продукт або послугу, що з'являються в 3МІ (газетах, телепередачах тощо);

- взаємовідносини з персоналом - внутрішні комунікації закладу зі своїми підлеглими, основою яких $\epsilon$ програми мотивації працівників до здійснення своєї роботи якнайкраще;

- взаємовідносини $з$ фінансовими організаціями - взаємодія 3 державними фінансовими органами, 3 приватними і корпоративними інвесторами, з фондовими брокерами та фінансовою пресою;

- взаємовідносини з владними структурами - тісна співпраця з всеукраїнськими, регіональними i місцевими органами влади;

- взаємовідносини 3 місцевим населенням - підтримку гарних відносин 3 місцевими жителями, включає спонсорство, наприклад, допомога у розв'язанні екологічних проблем міста чи регіону.

Методами PR в закладах громадського харчування є: співпраця зі ЗМI, Інтернет-просування, продакт-плейсмент, спеціальні події, сарафанне радіо, конкурси та розіграші призів.

PR-технології - це сукупність методів, прийомів, технік, за рахунок яких впливають на громадську думку з метою ефективного керування нею. Завданнями цих технологій є: створення загальної думки ресторан, його власника, продукцію, послуги; аналіз будь-якої ситуації, що відбулася в ресторані, формування рекомендацій з будь-якого питання [3, с.29].

Будь-яка PR-технологія являється інтегрованою системою, яка складається з власних проблем, цілей, функцій, форм, ресурсів та результатів господарської діяльності. Отже, варто розглядати типові заходи більшості технологій «Public relations», що складаються з 4 головних етапів (рис. 1).

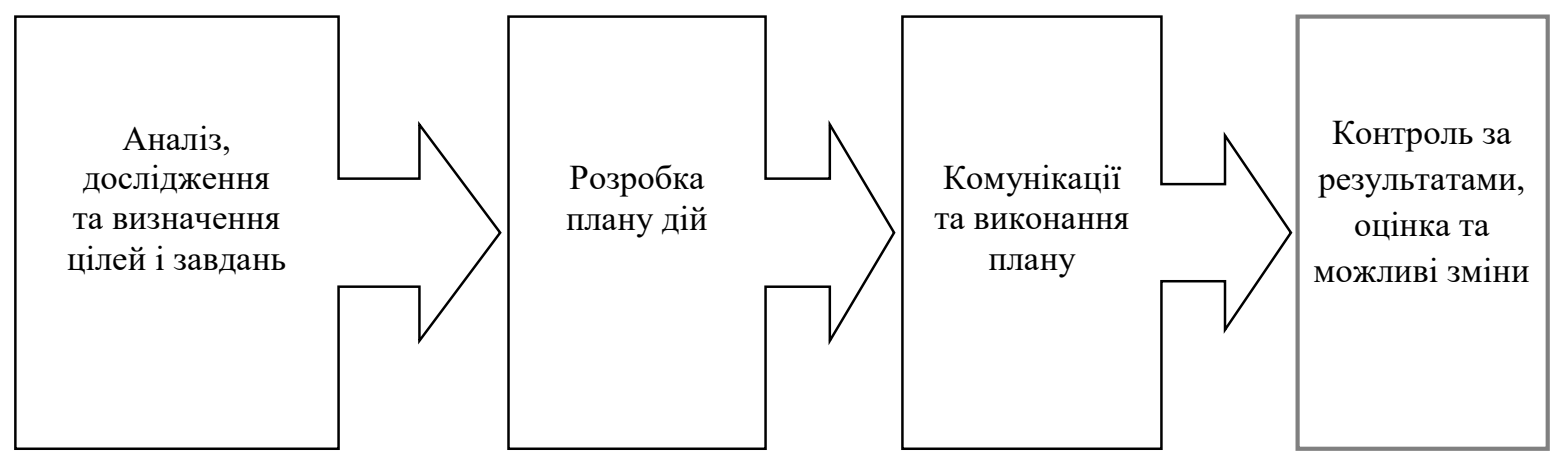

Рис. 1. Етапи основних програм більшості технологій «Public relations»

Дана послідовність охарактеризована управлінською функцією PR, що є невід'ємною складовою при створенні комплексу технологій, які застосовуються в будь-яких закладах громадського харчування.

Масштаби взаємовідносин, спрямовані на розвиток міцних зв'язків із громадськістю, можуть бути найрізноманітнішими залежно від величини і характеру сторін, але філософія, стратегія і методи залишаються дуже подібними, яка б не була поставлена мета, наприклад, поліпшення стосунків між закладом і споживачами їі ресторанної продукції, клієнтами і працівниками.

Фахівці Public relations у сфері громадського харчування застосовують новітні прийоми спілкування та переконання для створення «мостів» і формування взаєморозуміння.

Взаєморозумінню слугують репутація, значний досвід та культурні фактори. Важливі компоненти більшості програм PR у сфері громадського харчування із формуванням надійної репутації - створення атмосфери довіри та втілення єдиної стратегії.

Засоби PR у відносинах із громадськістю наведені в таблиці 2. Робота з громадськістю у бізнесі - це формування попиту на бізнесову фізичну чи організаційну одиницю методом розповсюдження про неї важливої інформації, що має престижний характер у засобах масової інформації. 
Головні засоби Public relations, щчо використовують заклади громадського харчування

\begin{tabular}{|c|c|}
\hline Засіб & Характеристика \\
\hline Новини & $\begin{array}{l}\text { Фахівці зі зв’язків з громадськістю шукають або створюють історії з новинами про } \\
\text { компанію, ії товари або співробітників, що представляють їх в сприятливому світлі }\end{array}$ \\
\hline Публічні виступи & $\begin{array}{l}\text { Керівникам компаній доводиться відповідати на питання представників ЗМІ або виступати } 3 \\
\text { промовами на торгових зборах або зустрічах, і це може або поліпшити, або погіршити імідж компанії }\end{array}$ \\
\hline Друковані матеріали & $\begin{array}{l}\text { Матеріали включають щорічні звіти, брошури, статті, збірники та журнали з новинами про } \\
\text { компанію }\end{array}$ \\
\hline $\begin{array}{l}\text { Аудіовізуальні } \\
\text { матеріали }\end{array}$ & Фільми, слайди, відео-і аудіокасети \\
\hline $\begin{array}{l}\text { Матеріал, що } \\
\text { персоніфікує } \\
\text { компанію }\end{array}$ & $\begin{array}{l}\text { Логотип, канцелярське приладдя, брошури, бланки, візитки, будівлі, уніформа і навіть } \\
\text { автомобілі і вантажівки компанії }\end{array}$ \\
\hline Спонсорство & Будь-яка дія, за допомогою якої корпорації набувають визнання громадськості \\
\hline Фандрейзинг & $\begin{array}{l}\text { Процес залучення грошових засобів та інших ресурсів (людських, матеріальних, } \\
\text { інформаційних), які організація не може забезпечити самостійно і які є необхідними для } \\
\text { реалізації певного проекту або власної діяльності в цілому }\end{array}$ \\
\hline Web-сторінка & $\begin{array}{l}\text { Споживачі та інші представники громадськості відвідують сторінку для отримання } \\
\text { інформації або просто заради інтересу }\end{array}$ \\
\hline
\end{tabular}

Зовнішніми PR-інструментами, що використовують заклади громадського харчування $\epsilon[4$, c. 65$]$ :

1. Інтернет: офіційний сайт, соціальні мережі, блоги, розсилки та інше;

2. МІ: друковані, телебачення, радіо, заходи для преси;

3. Ділові заходи: форуми, семінари, тренінги, виставки, ярмарки та інше;

4. Соціальні заходи: спонсорство, благодійність, соціальна відповідальність;

5. Спеціальні заходи: премії, круглі столи, презентації, конкурси та інше;

6. Зовнішні комунікації: інтерв’ю, участь у рейтингах ресторанів (міжнародні, регіональні);

Внутрішніми PR-інструментами, що використовують заклади громадського харчування, $\epsilon$ :

1. Інформаційні: корпоративні ЗМІ (буклети, корпоративне ТБ), розсилки, стенди, листівки, голосові повідомлення та ін.;

2. Аналітичні: анкетування персоналу, опитування, моніторинг та інше;

3. Комунікаційні: корпоративні свята, підвищення кваліфікації, програми адаптації та інше;

4. Організаційні: збори колективу, наради, корпоративні стандарти та інше.

Застосування різних засобів маркетингових комунікацій залежить від цільової аудиторії, на яку вони спрямовані, інтенсивності присутності ресторанного закладу на ринку, особливостей його бізнесповедінки, концептуалізації, досвіду, традицій тощо.

Одним із головних засобів PR в закладах громадського харчування є ресторанна критика. Обов'язковим в даному засобі $є$ елемент критичної оцінки - не тільки кухні, а й всього ресторану в цілому.

Зважаючи на те, що Інтернет надає неабиякі можливості для вдосконалення технологій просування послуг, дуже важливо забезпечити он-лайн присутність закладу громадського харчування в повному обсязі і зробити це якнайкраще й швидше, ніж головні конкуренти. При ефективному керуванні та застосуванні PRменеджерами Інтернет дозволяє суттєво збільшити відвідуваність підприємств громадського харчування, наприклад за допомогою можливості резервування столиків, ознайомлення 3 меню та цінами та інше. Інтернет-сайт ресторану як засіб PR $€$ дуже важливим. Якщо Інтернет-сайт створено грамотно, то пошукові системи одразу підтягують заклад громадського харчування на найвищі позиції в результатах пошуку.

Висновки і пропозиції. Застосування різноманітних PR-технологій, перш за все полягає в тому, щоб максимально впливати на суспільство, використовуючи різні засоби піару, для формування високої суспільної репутації і популярності фірми. Сучасні технології Public relations в закладах громадського харчування мають за мету створення унікального образу того чи іншого ресторану, формування позитивної думки громадськості, покращення різними методами ділової репутації для успішного функціонування на ринку. Можна сказати, що Public relations на підприємствах громадського харчування - так звана функція бізнес-керування, що сприяє встановленню і підтримці спілкування, взаєморозуміння та співпраці між ресторанами та громадськістю. Встановлено, що в сьогоднішніх умовах ведення бізнесу громадського харчування он-лайн присутність - це обов'язковий елемент маркетингової стратегії просування закладу громадського харчування. Варто пам'ятати, що просування ресторанного закладу не сприймається як окрема періодична PR-кампанія, а сприймається як щоденна копітка робота.

\section{Список використаної літератури:}

1. Ансофф И. Новая корпоративная стратегия / И.Ансофф. - СПб. : Питер, 1999. - 416 с.

2. Білик I.B. Роль маркетингу та PR-технологій у діяльності закладів готельно-ресторанного бізнесу / I.В. Білик, Т.С. Томаля // Економіка. Управління. Інновації. - 2014. - № 1 [Електронний ресурс]. - Режим доступу : http://nbuv.gov.ua/UJRN/eui_2014_1_7. 
3. Буторіна В.Б. Іміджеологія і PR підприємств туристичної галузі : навчально-методичний посібник / В.Б. Буторіна. - Кам’янець-Подільський : ПП «Медобори-2006», 2015. - 112 с.

4. Вовчанська О.М. Конфігурація складників PR-технологій у ресторанному бізнесі / О.М. Вовчанська, Л.О. Іванова, Н.Р. Балук // Вісник Одеського національного університету / Серія : Економіка. - 2018. Т. 23, Вип. 3. - С. 62-68.

5. Гладских E. Обзор ресторанного рынка / Е.Гладских [Електронный ресурс]. - Режим доступа : https://delo.ua/lifestyle/sytnyj-god-obzor-restorannogorynka-329410.htm.

6. Котлер Ф. Маркетинг менеджмент / Ф.Котлер, К.Л. Келлер. - СПб. : Питер, 2006. - 816 с.

7. Ламбен Жан-Жак Стратегический маркетинг. Европейская перспектива / Жан-Жак Ламбен ; пер. с фр. СПб. : Наука, 1996. - 589 с.

8. Портер M.E. Конкурентное преимущество: Как достичь высокого результата и обеспечить его устойчивость / M.E. Портер ; пер. с англ. - М. : Альпина Бизнес Букс, 2005. - 715 с.

9. Триси М. Маркетинг ведущих компаний. Выбери потребителя, определи фокус, доминируй на рынке / М.Триси, Ф.Виерсема. - М. : Вильямс, 2007. - 304 с.

10. Hamel G. Competing for the Future: Breakthrough Strategies for Seizing Control of Your Industry and Creating Markets of Tomorrow / G.Hamel, C.K. Prahalad. - Boston : Harvard Business School Press, 1994. - 327 p.

11. Mintzberg H. The Rise and Fall of Strategic Planning / H.Mintzberg. - N.Y. : The Free Press, 1994. -416 p.

12. Prahalad C.K. The core competence of the corporation / C.K. Prahalad, G.Hamel // Harvard Business Review. 1990. - Vol. 68, No. 3. - P. 79-91.

13. Teece D. Dynamic Capabilities and Strategic Management / D.Teece, G.Pisano, A.Shuen // Strategic Management Journal. - 1997. - Vol. 18, No. 7. - P. 509-533.

14. Treacy M. The Discipline of Market Leaders: Choose Your Customers, Narrow Your Focus, Dominate Your Market / M.Treacy, F.Wiersema. - MA : Addison-Wesley, 1995. - 208 p.

\section{References:}

1. Ansoff, I. (1999), Novaya korporativnaya strategiya, Piter, SPb., 416 p.

2. Bilyk, I.V. and Tomalja, T.S. (2014), «Rol' marketyngu ta PR-tehnologij u dijal'nosti zakladiv gotel'norestorannogo biznesu», Ekonomika. Upravlinnja. Innovacii', No. 1, [Online], availavle at: http://nbuv.gov.ua/UJRN/eui_2014_1_7

3. Butorina, V.B. (2015), Imidzheologija i PR pidpryjemstv turystychnoi' galuzi, navchal'no-metodychnyj posibnyk , PP «Medobory-2006», Kam'janec'-Podil's'kyj, 112 p.

4. Vovchans'ka, O.M., Ivanova, L.O. and Baluk, N.R. (2018), «Konfiguracija skladnykiv PR-tehnologij u restorannomu biznesi», Visnyk Odes'kogo nacional'nogo universytetu, Serija Ekonomika, T. 23, Vyp. 3, pp. $62-68$.

5. Gladskikh, E., Obzor restorannogo rynka, [Online], availavle at: https://delo.ua/lifestyle/sytnyj-god-obzorrestorannogorynka-329410.htm

6. Kotler, F. and Keller, K.L. (2006), Marketing menedzhment, Piter, SPb., 816 p.

7. Lamben, Zhan-Zhak (1996), Strategicheskii marketing. Evropeiskaya perspektiva, per. s fr., Nauka, SPb., 589 p.

8. Porter, M.E. (2005), Konkurentnoe preimushchestvo: Kak dostich' vysokogo rezul'tata i obespechit' ego ustoichivost'; per. s angl., Al'pina Biznes Buks, M., 715 p.

9. Trisi, M. and Viersema, F. (2007), Marketing vedushchikh kompanii. Vyberi potrebitelya, opredeli fokus, dominirui na rynke, Vil'yams, M., $304 \mathrm{p}$.

10. Hamel, G. and Prahalad, C.K. (1994), Competing for the Future: Breakthrough Strategies for Seizing Control of Your Industry and Creating Markets of Tomorrow, Harvard Business School Press, Boston, 327 p.

11. Mintzberg, H. (1994), The Rise and Fall of Strategic Planning, The Free Press, N.Y., 416 p.

12. Prahalad, C.K. and Hamel, G. (1990), «The core competence of the corporation», Harvard Business Review, Vol. 68, No. 3, pp. 79-91.

13. Teece, D., Pisano, G. and Shuen, A. (1997), «Dynamic Capabilities and Strategic Management», Strategic Management Journal, Vol. 18, No. 7, pp. 509-533.

14. Treacy, M. and Wiersema, F. (1995), The Discipline of Market Leaders: Choose Your Customers, Narrow Your Focus, Dominate Your Market, Addison-Wesley, MA, 208 p.

Могилова Анастасія Юріївна - доктор економічних наук, професор, професор кафедри маркетингу та міжнародного менеджменту Дніпровського національного університету імені Олеся Гончара.

Наукові інтереси:

- стратегічний менеджмент;

- управління промисловими підприємствами;

- капіталізація компаній;

- вартість бізнесу;

- стратегічний маркетинг.

Вознюк Максим Андрійович - магістр Дніпровського національного університету імені Олеся Гончара. Наукові інтереси:

- стратегічний менеджмент;

- управління промисловими підприємствами;

- капіталізація компаній;

- вартість бізнесу;

- стратегічний маркетинг. 